\title{
Patient Experience in Home Respiratory Therapies: Where We Are and Where to Go
}

\author{
Cátia Caneiras $1,2, t, * \mathbb{(})$, Cristina Jácome ${ }^{3,4,+}\left(\mathbb{D}\right.$, Sagrario Mayoralas-Alises ${ }^{5,6}$, José Ramon Calvo ${ }^{6}$, \\ João Almeida Fonseca ${ }^{3,7,8}$, Joan Escarrabill ${ }^{9,10,11}$ and João Carlos Winck ${ }^{12}$ \\ 1 Institute of Environmental Health (ISAMB), Faculty of Medicine, Universidade de Lisboa, \\ 1649-028 Lisboa, Portugal \\ 2 Healthcare Department, Praxair Portugal Gases, 2601-906 Lisboa, Portugal \\ 3 CINTESIS-Center for Health Technologies and Information Systems Research, Faculty of Medicine, \\ University of Porto, 4200-450 Porto, Portugal; cjacome@med.up.pt (C.J.); fonseca.ja@gmail.com (J.A.F.) \\ 4 Respiratory Research and Rehabilitation Laboratory (Lab3R), School of Health Sciences (ESSUA), \\ University of Aveiro, 3810-193 Aveiro, Portugal \\ 5 Service of Pneumology, Hospital Universitario Moncloa, 28008 Madrid, Spain; sarimayoralas@gmail.com \\ 6 Healthcare Department, Praxair Spain, 28020 Madrid, Spain; jose_ramon_calvo@praxair.com \\ 7 MEDCIDS-Department of Community Medicine, Health Information and Decision, Faculty of Medicine, \\ University of Porto, 4200-450 Porto, Portugal \\ 8 Allergy Unit, Instituto and Hospital CUF, 4460-188 Porto, Portugal \\ 9 Hospital Clínic de Barcelona, 08036 Barcelona, Spain; ESCARRABILL@clinic.cat \\ 10 Master Plan for Respiratory Diseases (Ministry of Health) \& Observatory of Home Respiratory \\ Therapies (FORES), 08028 Barcelona, Spain \\ 11 REDISSEC Health Services Research on Chronic Patients Network, Instituto de Salud Carlos III, \\ 28029 Madrid, Spain \\ 12 Faculty of Medicine, University of Porto, 4200-319 Porto, Portugal; jcwinck@mail.telepac.pt \\ * Correspondence: ccaneiras@gmail.com; Tel.: +351-912-556-452 \\ + These authors contributed equally to this work.
}

Received: 5 March 2019; Accepted: 23 April 2019; Published: 24 April 2019

\begin{abstract}
The increasing number of patients receiving home respiratory therapy (HRT) is imposing a major impact on routine clinical care and healthcare system sustainability. The current challenge is to continue to guarantee access to HRT while maintaining the quality of care. The patient experience is a cornerstone of high-quality healthcare and an emergent area of clinical research. This review approaches the assessment of the patient experience in the context of HRT while highlighting the European contribution to this body of knowledge. This review demonstrates that research in this area is still limited, with no example of a prescription model that incorporates the patient experience as an outcome and no specific patient-reported experience measures (PREMs) available. This work also shows that Europe is leading the research on HRT provision. The development of a specific PREM and the integration of PREMs into the assessment of prescription models should be clinical research priorities in the next several years.
\end{abstract}

Keywords: Long-term oxygen therapy; home mechanical ventilation; patient-reported experience measures; quality of care; healthcare; sustainability

\section{Introduction}

Long-term oxygen therapy (LTOT) and/or home mechanical ventilation (HMV) are well-established therapies for patients with chronic respiratory failure, such as those with chronic obstructive pulmonary disease (COPD), neuromuscular diseases, and obstructive sleep apnea (OSA), among others. These 
therapies represent key services in the home respiratory therapy (HRT) provided to these patients. Increasing numbers of patients receiving HRT are reported not only in Europe but also worldwide [1-5]. Thus, HRT is imposing a major impact on clinical care and healthcare systems. Over the next several years, the main challenge will be to ensure a sustainable healthcare system to continue to guarantee access to HRT while maintaining the quality of care.

According to the World Health Organization, quality of care is defined as "the extent to which health care services provided to individuals and patient populations improve desired health outcomes. In order to achieve this, health care must be safe, effective, timely, efficient, equitable and people-centered" [6]. A necessary step in the process of maintaining and improving quality is to monitor and evaluate the quality of healthcare in routine clinical practice. Based on the reactive, disease-focused, and biomedical model, the indicators of quality have been mainly restricted to traditional clinical metrics. A number of studies conducted over the last few decades have addressed the beneficial effects of HRT on morbidity, mortality, and adverse outcomes, as well as the variations in HRT provision among countries [5,7,8]. However, these metrics alone do not provide a complete picture of HRT quality.

The patient's experience of treatment is a cornerstone of high-quality healthcare [9]. Only by analyzing the relational and functional aspects of the patient experience is it possible to assess the extent to which patients are receiving care that is in line with their preferences, needs, and values. The integration of the patient experience with healthcare delivery and quality evaluation are key steps in moving toward patient-centered and personalized care [10]. As Doyle et al. suggested, the patient's experience is the third pillar of quality, along with clinical safety and effectiveness [11]. However, it is only in recent years that patients' perceptions of healthcare provision have started to receive attention.

This review approaches the assessment of the patient experience in the clinical context of HRT while highlighting the European contribution to this emerging body of knowledge.

\section{Patient Experience in the Context of HRT}

The patient experience in the context of HRT is reviewed with a focus on two main areas: (1) HRT prescription models and the inclusion of the patient experience as an outcome of these models and (2) methods used to assess the patient experience. To address these two aims, a narrative review was conducted. The search, although not systematic in nature, included searches in electronic databases (PubMed, Medline, ISI Web of Knowledge and Google Scholar), as well as hand searches (expert consultation and a review of the reference lists in the included papers). The databases were searched between July and December 2018 using topic-related terms, such as oxygen therapy, home mechanical ventilation, noninvasive mechanical ventilation, home respiratory therapy, home treatment, chronic respiratory insufficiency, chronic respiratory failure, epidemiology, prescription, quality control, outcomes, patient experience, patient perspective, carers, caregivers, patient-reported experience measure, questionnaires, interviews, and focus groups. There was no time restriction in the literature search, although it was limited to English, Portuguese, or Spanish.

\subsection{Prescription Models of HRT}

There are a number of studies that have assessed the prescription of HRT. Table 1 summarizes 15 relevant studies on this topic. The majority of the studies $(n=9)$ were conducted from 2009 onward and primarily assessed the prescription of HMV $(n=10)$ [4,5,12-19], followed by LTOT $(n=6)$ [19-24]. The estimated prevalence of HMV (from 2.5 to $23 / 100,000$ population) and of LTOT (from 31.6 to $102 / 100,000$ population) were variable among distinct regions or countries. The estimated prevalence of HMV in Europe was 6.6 per 100,000 people, and Portugal was one of the countries with the highest prevalence [5].

Three studies reported the assessment of HRT prescription at a regional level (Catalan, Spain; Hong Kong, China; Tasmania, Australia), eight at a national level (Sweden, Canada, Poland, Denmark, England, Australia, France, Spain), and four at an international level (two countries, seven countries, 13 European countries, 16 European countries). 
Table 1. Studies assessing the prescription of home respiratory therapies.

\begin{tabular}{|c|c|c|c|c|c|}
\hline $\begin{array}{l}\text { Author, } \\
\text { Year }\end{array}$ & $\begin{array}{l}\text { Region or Country, } \\
\text { Years Analyzed }\end{array}$ & Aim & Method & Data Collection & Results \\
\hline $\begin{array}{l}\text { Ekström et al., } \\
2017 \text { [20] }\end{array}$ & Sweden, 1987-2015 & $\begin{array}{l}\text { Long-term oxygen } \\
\text { therapy (LTOT): incidence, } \\
\text { prevalence, and the } \\
\text { quality of prescription } \\
\text { and management }\end{array}$ & $\begin{array}{l}\text { Data from the Swedevox registry } \\
\text { between } 1 \text { January } 1987 \text { and } 31 \\
\text { December } 2015\end{array}$ & $\begin{array}{l}\text { Data: } \\
\text { Birth date, } \\
\text { Sex, } \\
\text { Primary/secondary causes of LTOT, } \\
\text { Follow-up, } \\
\text { Stop date and stop cause, } \\
\mathrm{PaO}_{2} \text { air and } \mathrm{PaCO}_{2} \text { air, } \\
\mathrm{PaO}_{2} \text { oxygen and } \mathrm{PaCO}_{2} \text { oxygen, } \\
\mathrm{FEV}_{1} \text { and } \mathrm{VC}, \\
\text { World Health Organization performance status, } \\
\text { Height and weight, } \\
\text { Never/Past/Current smoker, } \\
\text { Maintenance treatment with oral corticosteroids, } \\
\text { Oxygen dose, } \\
\text { Oxygen duration. }\end{array}$ & $\begin{array}{l}23,909 \text { patients on LTOT. } \\
48 \text { respiratory or medicine units. } \\
\text { Incidence of LTOT increased from } 3.9 \text { to } \\
14.7 / 100,000 \text { inhabitants over the study time } \\
\text { period. } \\
\text { In } 2015,2596 \text { patients had ongoing therapeutic } \\
\text { LTOT in the registry, a prevalence of } 31.6 / 100,000 \text {. } \\
\text { Adherence to prescription recommendations and } \\
\text { fulfilment of quality criteria were stable or } \\
\text { improved over time. } \\
\text { Of patients starting LTOT in } 2015,88 \% \text { had severe } \\
\text { hypoxemia and } 97 \% \text { had any degree of hypoxemia; } \\
98 \% \text { were prescribed oxygen for } \geq 15 \text { hours/day; } \\
76 \% \text { had both stationary and mobile oxygen } \\
\text { equipment; } 75 \% \text { had a mean PaO }>8.0 \mathrm{kPa} \\
\text { breathing oxygen; and } 98 \% \text { were non-smokers. } \\
\text { Response rate } 152 / 171(89 \%) \text {. }\end{array}$ \\
\hline $\begin{array}{l}\text { Rose et al., } \\
2015 \text { [12] }\end{array}$ & Canada, 2012-2013 & $\begin{array}{l}\text { Home mechanical } \\
\text { ventilation (HMV): } \\
\text { national data profiling }\end{array}$ & $\begin{array}{l}\text { Survey administered via a web } \\
\text { link from August } 2012 \text { to April } \\
2013 \text { to service providers } \\
\text { delivering care/services to } \\
\text { ventilator-assisted individuals } \\
\text { requiring daily noninvasive } \\
\text { ventilation (NIV) or invasive } \\
\text { mechanical ventilation via } \\
\text { tracheostomy at home. }\end{array}$ & $\begin{array}{l}\text { Survey content: } \\
\text { provider characteristics, including services and } \\
\text { education provided; } \\
\text { user characteristics (age, ventilation type, primary } \\
\text { disorder, duration of ventilation); } \\
\text { criteria for initiation and monitoring ventilation } \\
\text { effectiveness; equipment (ventilators and } \\
\text { interfaces used, ventilator servicing arrangements } \\
\text { and backup); } \\
\text { training and education (audience, structure, topics, } \\
\text { ongoing competency assessment); } \\
\text { liaisons and transitions (referral, barriers to } \\
\text { transition); } \\
\text { follow-up (structure, frequency, location). }\end{array}$ & $\begin{array}{l}4334 \text { ventilator-assisted individuals: an estimated } \\
\text { prevalence of } 12.9 / 100,000 \text { population. } \\
73 \% \text { receiving NIV and } 18 \% \text { receiving intermittent } \\
\text { mandatory ventilation }(9 \% \text { not reported). } \\
\text { Services were delivered by } 39 \text { institutional } \\
\text { providers and } 113 \text { community providers. } \\
\text { Various models of ventilator servicing were } \\
\text { reported. } \\
64 \% \text { of providers stated that caregiver competency } \\
\text { was a prerequisite for home discharge, but } \\
\text { repeated competency assessment and retraining } \\
\text { were offered by } 45 \% \text {. } \\
\text { Barriers to home transition: insufficient funding } \\
\text { for paid caregivers, equipment, and supplies; } \\
\text { a shortage of paid caregivers; negotiating public } \\
\text { funding arrangements. }\end{array}$ \\
\hline
\end{tabular}


Table 1. Cont.

\begin{tabular}{|c|c|c|c|c|c|}
\hline $\begin{array}{l}\text { Author, } \\
\text { Year }\end{array}$ & $\begin{array}{l}\text { Region or Country, } \\
\text { Years Analyzed }\end{array}$ & Aim & Method & Data Collection & Results \\
\hline $\begin{array}{l}\text { Escarrabill et al., } \\
2015 \text { [13] }\end{array}$ & $\begin{array}{l}\text { Catalan Health } \\
\text { Service (Spain), } \\
\text { 2008-2011 }\end{array}$ & $\begin{array}{l}\text { HMV: prevalence and } \\
\text { variability in prescriptions }\end{array}$ & $\begin{array}{l}\text { Catalan Health Service (CatSalut) } \\
\text { billing database, between } 2008 \\
\text { and } 2011 .\end{array}$ & Not reported (NR) & $\begin{array}{l}240,760 \text { patients received some type of HRT } \\
\text { funded by the public system. } \\
75.8 \% \text { used continuous positive airway pressure } \\
\text { equipment, } 17.3 \% \text { used various forms of oxygen } \\
\text { supply, } 4.2 \% \text { used nebulized therapy, } 2.5 \% \text { used } \\
\text { HMV, and } 0.2 \% \text { used miscellaneous treatments. } \\
6,867 \text { patients received HMV, } 23 \text { users per } 100,000 \\
\text { population. } \\
\text { Rates of HMV increased by } 39 \% \text { over the study } \\
\text { period }\end{array}$ \\
\hline $\begin{array}{l}\text { Nasiłowski et al., } \\
2015 \text { [14] }\end{array}$ & Poland, 2000-2010 & $\begin{array}{l}\text { HMV: trends over the last } \\
\text { decade }\end{array}$ & $\begin{array}{l}\text { Questionnaire designed } \\
\text { specifically for the study was sent } \\
\text { to the heads of nine HMV centers }\end{array}$ & $\begin{array}{l}\text { Survey Content: } \\
\text { Center details: location, area of activity } \\
\text { (uniregional/multiregional), and year of initiating } \\
\text { HMV. } \\
\text { Number of subjects treated with HMV in each } \\
\text { consecutive year. } \\
\text { Overall number of treated subjects, divided into } \\
\text { five disease categories: } \\
\text { (1) neuromuscular diseases, } \\
\text { (2) lung diseases (chronic obstructive pulmonary } \\
\text { disease (COPD), bronchiectasis, cystic fibrosis, } \\
\text { interstitial diseases), } \\
\text { (3) chest-wall diseases (scoliosis, thoracoplasty, } \\
\text { ankylosing spondylitis, post-tuberculosis } \\
\text { sequelae), } \\
\text { (4) hypoventilation syndromes (due to obesity, } \\
\text { central congenital hypoventilation syndrome, } \\
\text { central sleep apnea), } \\
\text { (5) other diseases. } \\
\text { Technique of ventilation (invasive and } \\
\text { noninvasive). } \\
\text { Number of new cases; } \\
\text { Overall number of subjects treated with NIV or } \\
\text { tracheostomy. } \\
\text { Age of the treated subjects, } \\
\text { Site where ventilation was initiated: intensive care } \\
\text { unit, respiratory department, neurology } \\
\text { department, general medicine department, home, } \\
\text { or other. }\end{array}$ & $\begin{array}{l}\text { Nine HMV centers, } 1495 \text { subjects } \\
\text { Center experience } 9 \pm 3 \text { years ( } 6-13 \text { years) } \\
\text { One center was dedicated specifically to children, } \\
\text { Two solely treated adults, and other centers } \\
\text { treated subjects irrespective of age. } \\
\text { In } 2010 \text {, prevalence of HMV reached almost } 2.5 \\
\text { subjects/100,000. } \\
\text { The majority of subjects on HMV suffered from } \\
\text { neuromuscular diseases ( } 100 \% \text { in } 2000-2002 \text { to } \\
51 \% \text { in } 2010 \text { ). } \\
\text { Subjects with a diagnosis of respiratory failure } \\
\text { due to pulmonary conditions appeared in } 2004 \\
\text { and the number of subjects rapidly increased } \\
\text { beginning in } 2007 \text {. In } 2010 \text {, they accounted for } \\
\text { almost } 25 \% \text { of all HMV cases. } \\
\text { Hypoventilation syndromes were the third main } \\
\text { diagnostic group ( } 4 \% \text { until } 2008, \text { reaching } 11 \% \text { in } \\
2010) \text {. } \\
\text { Proportion of chest-wall diseases remained } 3 \% \text {. } \\
\text { In } 2000 \text { and } 2001 \text {, ventilation via tracheostomy } \\
\text { was exclusively used. } \\
\text { The first subjects on NIV were treated in } 2002 \text {. The } \\
\text { number of subjects on NIV was } 1 / 3 \text { in } 2004 \text { and } \\
\text { then leveled off for the following five years, } \\
\text { followed by a rapid increase until } 2010, \text { when the } \\
\text { proportions of subjects treated with NIV and } \\
\text { tracheostomy equalized. Since } 2008, \text { the number } \\
\text { of new cases treated noninvasively surpassed the } \\
\text { number of new cases treated with invasive } \\
\text { ventilation, and in } 2010, \text { the total number of } \\
\text { subjects in both groups was virtually the same. }\end{array}$ \\
\hline
\end{tabular}


Table 1. Cont.

\begin{tabular}{|c|c|c|c|c|c|}
\hline $\begin{array}{l}\text { Author, } \\
\text { Year }\end{array}$ & $\begin{array}{l}\text { Region or Country, } \\
\text { Years Analyzed }\end{array}$ & Aim & Method & Data Collection & Results \\
\hline $\begin{array}{l}\text { Garner et al., } 2013 \\
\text { [15] }\end{array}$ & $\begin{array}{l}\text { Australia and New } \\
\text { Zealand, 2002-2004 }\end{array}$ & HMV & $\begin{array}{l}\text { HMV centers that had prescribed } \\
\text { HMV for more than three months } \\
\text { to more than five adult patients. } \\
\text { A designed survey. }\end{array}$ & $\begin{array}{l}\text { Survey Content: } \\
\text { (1) Institutional details: location, type (e.g., } \\
\text { tertiary), funding (e.g., government), patient } \\
\text { catchment, years of service; } \\
\text { (2) Criteria for HMV prescription by disease group } \\
\text { (e.g., COPD); } \\
\text { (3) HMV service details: number of patients } \\
\text { receiving HMV, staffing levels, methods of } \\
\text { implementation by location/tests utilized/staff } \\
\text { involved, methods of follow-up by location/tests } \\
\text { utilized/staff involved (0-3 grading from never to } \\
\text { always), annual clinic attendances, presence of an } \\
\text { outreach service; } \\
\text { (4) Individual patient data (if available): age, } \\
\text { gender, primary indication for HMV, duration of } \\
\text { therapy, adherence to therapy, interface, machine } \\
\text { settings (mode, inspiratory positive airway } \\
\text { pressure, expiratory positive airway pressure, } \\
\text { back-up rate); } \\
\text { (5) Local database: current database for that center, } \\
\text { data collected, what data should be collected, } \\
\text { support for creation of a national database, center } \\
\text { willing to participate; } \\
\text { (6) Problems encountered with setting up an HMV } \\
\text { service. }\end{array}$ & $\begin{array}{l}28 \text { centers }(82 \%) \text { responded, providing data on } \\
2725 \text { patients. } \\
\text { Prevalence of HMV was } 9.9 \text { patients } / 100,000 \text { in } \\
\text { Australia and } 12.0 \text { patients } / 100,000 \text { in New } \\
\text { Zealand. } \\
\text { Variation existed among Australian states (range } \\
4-13 \text { patients/100,000) correlating with population } \\
\text { density }(r=0.82, p<0.05) \text {. } \\
\text { The commonest indications for treatment were } \\
\text { obesity hypoventilation syndrome (31\%) and } \\
\text { neuromuscular disease }(30 \%) \text {. } \\
\text { COPD was an uncommon indication }(8 \%) \text {. } \\
\text { No consensus on indications for commencing } \\
\text { treatment was found. }\end{array}$ \\
\hline
\end{tabular}


Table 1. Cont.

\begin{tabular}{|c|c|c|c|c|c|}
\hline $\begin{array}{l}\text { Author, } \\
\text { Year }\end{array}$ & $\begin{array}{l}\text { Region or Country, } \\
\text { Years Analyzed }\end{array}$ & Aim & Method & Data Collection & Results \\
\hline $\begin{array}{l}\text { Ringbaek et al., } \\
2013 \text { [21] }\end{array}$ & Denmark, 2001-2010 & $\begin{array}{l}\text { (LTOT: incidence, } \\
\text { prevalence, treatment } \\
\text { modalities, } \\
\text { and survival in COPD. }\end{array}$ & $\begin{array}{l}\text { Danish Oxygen Register in the } \\
\text { period from } 01 \text { January } 2001 \text { to } 31 \\
\text { December 2010: information on } \\
\text { patients on home oxygen therapy, } \\
\text { their prescriptions, and } \\
\text { termination of therapy. } \\
\text { National Health Services Central } \\
\text { Register: information on } \\
\text { diagnosis for LTOT and on vital } \\
\text { status up to } 31 \text { December } 2011 .\end{array}$ & NR & $\begin{array}{l}\text { On } 31 \text { Dec } 2001 \text {, a total of } 2247 \text { COPD patients } \\
(42.0 / 100,000) \text { were receiving LTOT. } \\
\text { The number of patients on LTOT had increased } \\
\text { constantly to reach a prevalence of } 48.1 / 100,000 \text { in } \\
2010 \text {. } \\
\text { Incidence of oxygen therapy increased } \\
\text { insignificantly from } 30.5 \text { to } 32.2 / 100,000 \text {. } \\
\text { The majority of COPD patients were women and } \\
\text { older than } 70 \text { years of age. The mean age of } \\
\text { patients who started LTOT during the study } \\
\text { period increased from } 73.4 \pm 9 \text { years to } 74.8 \pm 9.7 \\
\text { years. } \\
\text { Most of the COPD patients were prescribed } \\
\text { oxygen therapy by a hospital doctor immediately } \\
\text { after an acute hospitalization, and the number of } \\
\text { prescriptions from general practitioners was } \\
\text { continuously declining toward zero during the } \\
\text { study period. } \\
\text { An increasing number of the COPD patients were } \\
\text { prescribed oxygen at least } 15 \mathrm{~h} \text { daily and had } \\
\text { delivered oxygen concentrator and mobile oxygen, } \\
\text { whereas, in general, the oxygen flow remained } \\
\text { low ( }(\leq 1.5 \mathrm{~L} \text { /minute). } \\
\text { Compared with men, women started LTOT more } \\
\text { often in connection with hospitalization and more } \\
\text { often stopped LTOT within the first } 6 \text { months. } \\
\text { Women were prescribed a lower oxygen flow than } \\
\text { men and the treatment was more often specified to } \\
\text { take place for } 15-24 \mathrm{~h} \text { per day. }\end{array}$ \\
\hline
\end{tabular}


Table 1. Cont.

\begin{tabular}{|c|c|c|c|c|c|}
\hline $\begin{array}{l}\text { Author, } \\
\text { Year }\end{array}$ & $\begin{array}{l}\text { Region or Country, } \\
\text { Years Analyzed }\end{array}$ & Aim & Method & Data Collection & Results \\
\hline $\begin{array}{l}\text { Mandal et al., } 2013 \\
\text { [16] }\end{array}$ & England, NA & $\begin{array}{l}\text { HMV: prevalence of sleep } \\
\text { and ventilation diagnostic } \\
\text { and treatment services }\end{array}$ & $\begin{array}{l}\text { A short survey delivered by } \\
\text { email to } 101 \text { NHS Hospitals }\end{array}$ & $\begin{array}{l}\text { Survey content: } \\
\text { 10-item survey, focused on diagnostic services and } \\
\text { HMV provision: } \\
\text { (a) availability of diagnostics, } \\
\text { (b) funding; } \\
\text { (c) patient groups. }\end{array}$ & $\begin{array}{l}76(68 \%) \text { responses received; } \\
42(55 \%) \text { trusts reported the provision of an HMV } \\
\text { service. } \\
\text { Only } 65 \% \text { of units charged for the delivery of } \\
\text { an HMV service, with } 12 \% \text { of these services } \\
\text { commissioned by an external provider. } \\
\text { Median set-up frequency for the units charging } \\
\text { was } 42 \text { patients per annum (interquartile range } \\
23-73) \text {, whereas those units that failed to charge } \\
\text { had a median of } 11 \text { (interquartile range } 4-22) \text {. } \\
\text { Of all the HMV set-ups, } 67 \% \text { were for } \\
\text { obesity-related respiratory failure and COPD, } \\
\text { with the other restrictive lung conditions forming } \\
\text { the remainder }\end{array}$ \\
\hline $\begin{array}{l}\text { Serginson et al., } \\
2009 \text { [22] }\end{array}$ & Australia, 2004-2005 & $\begin{array}{l}\text { LTOT: prescription and } \\
\text { costs }\end{array}$ & $\begin{array}{l}\text { Data from all LTOT services in } \\
\text { Australian Government's } \\
\text { departments and health services } \\
\text { (state and federal) } \\
\text { Centralized departments } \\
\text { managing } \\
\text { state budgets for LTOT provided } \\
\text { costs (for the financial year } \\
\text { 2004-2005) and patient numbers } \\
\text { (point prevalence in 2005). } \\
\text { If centralized data were not } \\
\text { available, regional departments } \\
\text { administering LTOT services } \\
\text { were contacted. }\end{array}$ & $\begin{array}{l}\text { Data: } \\
\text { Costs were defined as "equipment only" (fees } \\
\text { paid to oxygen companies) or "equipment and } \\
\text { administrative" (wages and non-labor costs of } \\
\text { administering programs included). }\end{array}$ & $\begin{array}{l}20,127 \text { patients }(100 / 100,000) \text { through } 59 \text { different } \\
\text { services at a cost of over } \$ 31 \text { million. } \\
\text { Prescription rates for LTOT per } 100,000 \text { population } \\
\text { within each state ranged from } 44 \text { to } 133, \text { a } \\
\text { threefold difference. } \\
\text { Costs of LTOT per patient prescribed per year } \\
\text { funded by individual states and territories ranged } \\
\text { from } \$ 1014 \text { to } \$ 2574 \text {. } \\
\text { The cost of oxygen concentrators averaged } \$ 85 \text { per } \\
\text { month (range, } \$ 29-\$ 109) \text {, portable oxygen ranged } \\
\text { from } \$ 16 \text { to } \$ 35 \text { per month without refills, and, } \\
\text { with a conserver included, } \$ 55 \text { (two refills) to } \$ 166 \\
\text { unlimited refills) per month. } \\
\text { All services provided concentrators for home use. } \\
\text { Portable oxygen was funded in all states, except } \\
\text { one (where it was limited to children and patients } \\
\text { waiting for heart or lung transplants). }\end{array}$ \\
\hline
\end{tabular}


Table 1. Cont

\begin{tabular}{|c|c|c|c|c|c|}
\hline $\begin{array}{l}\text { Author, } \\
\text { Year }\end{array}$ & $\begin{array}{l}\text { Region or Country, } \\
\text { Years Analyzed }\end{array}$ & Aim & Method & Data Collection & Results \\
\hline $\begin{array}{l}\text { Jones et al., } 2007 \\
\text { [23] }\end{array}$ & $\begin{array}{l}\text { Tasmania } \\
\text { (Australia), } \\
\text { 2002-2004 }\end{array}$ & LTOT & $\begin{array}{l}\text { Records of all patients receiving } \\
\text { Tasmanian } \\
\text { Government-funded LTOT } \\
\text { between } \\
\text { December } 2002 \text { and April } 2004\end{array}$ & $\begin{array}{l}\text { Data: } \\
\text { Recipient demographics, } \\
\text { Indications for LTOT, } \\
\text { Oxygen prescription, } \\
\text { Time to follow-up. } \\
\text { The service provider provided usage reports and } \\
\text { costs. }\end{array}$ & $\begin{array}{l}\text { April 2004: } 490 \text { patients receiving LTOT } \\
\text { Rate of } 102 / 100,000 \text {; } \\
\text { Median age at prescription of LTOT was } 71.5 \\
\text { (range } 0.7-97.2) \text { years, and } 54 \% \text { of patients were } \\
\text { female. } \\
\text { Oxygen was prescribed for } 267 \text { patients ( } 54 \% \text { ) } \\
\text { during hospitalization, although only } 192 \text { of these } \\
\text { patients ( } 72 \% \text { ) met criteria for oxygen use at this } \\
\text { time. } \\
\text { LTOT was prescribed by respiratory physicians for } \\
248 \text { patients (51\%) and by other hospital } \\
\text { physicians for most of the remaining patients } \\
(39 \%) \text {. } \\
\text { Data on indications were available for } 430 \text { patients } \\
(88 \%) \text {, and COPD accounted for } 48 \% \text { of } \\
\text { prescriptions, but this proportion varied regionally. } \\
\text { Median time to reassessment was } 5.5 \text { (range, } \\
0.1-116 \text { ) months, but varied between regions. } \\
\text { Usage data were available for } 175 \text { patients ( } 41 \%) \\
\text { using oxygen concentrators in April } 2004 \text {. Of these } \\
175 \text { patients, } 122 \text { (70\%) were prescribed oxygen for } \\
\text { COPD. In this group, the median use was } 18.3 \\
\text { (range, } 0.38-24 \text { ) hours per day; however, } 36 \text { ( } 30 \% \text { ) } \\
\text { had a median use }<15 \text { hours/day. }\end{array}$ \\
\hline
\end{tabular}


Table 1. Cont.

\begin{tabular}{|c|c|c|c|c|c|}
\hline $\begin{array}{l}\text { Author, } \\
\text { Year }\end{array}$ & $\begin{array}{l}\text { Region or Country, } \\
\text { Years Analyzed }\end{array}$ & Aim & Method & Data Collection & Results \\
\hline $\begin{array}{l}\text { Lloyd-Owen et al., } \\
2005 \text { [5] }\end{array}$ & $\begin{array}{l}16 \text { European } \\
\text { countries (Austria, } \\
\text { Belgium, Denmark, } \\
\text { Finland, France, } \\
\text { Germany, Greece, } \\
\text { Ireland, Italy, } \\
\text { Netherlands, } \\
\text { Norway, Poland, } \\
\text { Portugal, Spain, } \\
\text { Sweden, UK), } \\
\text { 2001-2002 }\end{array}$ & $\begin{array}{l}\text { HMV: patterns of use } \\
\text { across Europe }\end{array}$ & $\begin{array}{l}\text { Questionnaire of center details, } \\
\text { HMV user characteristics and } \\
\text { equipment choices sent to } \\
\text { selected HMV centers }\end{array}$ & $\begin{array}{l}\text { Survey Content: } \\
\text { Center (type of institution and year of starting } \\
\text { HMV), } \\
\text { Number of HMV users on 01 July 2001, } \\
\text { Users' characteristics (sex, age, and time on HMV). } \\
\text { Users' causes for respiratory failure: } \\
\text { (1) Lung: lung and airway diseases: COPD, cystic } \\
\text { fibrosis, bronchiectasis, pulmonary fibrosis, and } \\
\text { pediatric diseases, including bronchopulmonary } \\
\text { dysplasia; } \\
\text { (2) Thor: thoracic cage abnormalities: early-onset } \\
\text { kyphoscoliosis, tuberculosis sequelae such as } \\
\text { thoracoplasty, obesity hypoventilation syndrome, } \\
\text { and sequelae of lung resection; } \\
\text { (3) Neur: neuromuscular diseases: muscular } \\
\text { dystrophy, motor neuron disease (including } \\
\text { amyotrophic lateral sclerosis), post-polio } \\
\text { kyphoscoliosis, central hypoventilation, spinal } \\
\text { cord damage, and phrenic nerve paralysis. } \\
\text { Type of ventilator and interface used. }\end{array}$ & $\begin{array}{l}329 \text { centers completed surveys, } 21,526 \mathrm{HMV} \text { users, } \\
\text { Estimated prevalence of HMV was } 6.6 / 100,000 \text { in } \\
\text { the } 16 \text { European countries. } \\
\text { Differences between countries in the relative } \\
\text { proportions of (1) lung and neuromuscular } \\
\text { patients using HMV and (2) the use of } \\
\text { tracheostomies in lung and neuromuscular HMV } \\
\text { users. } \\
\text { Lung users were linked to an HMV duration of }<1 \\
\text { year, thoracic cage users with } 6-10 \text { years of } \\
\text { ventilation and neuromuscular users with a } \\
\text { duration of } \geq 6 \text { years. } \\
\text { Almost all of the HMV users had positive pressure } \\
\text { ventilators, with only } 0.005 \% \text { ( } 79 \text { users) having } \\
\text { other types. Volume preset positive pressure } \\
\text { ventilators were used the least for lung problems } \\
\text { and most frequently for neurological problems ( } \% \\
\text { volume: Lung } 15 \% \text {; Thor } 28 \% \text {; Neur } 41 \% \text { ). } \\
\text { Overall, } 13 \% \text { of the survey population had } \\
\text { ventilation via a tracheostomy with the highest } \\
\text { percentage in neuromuscular patients (Neur } 24 \% \text {; } \\
\text { Thor } 5 \% \text {; Lung } 8 \% \text { ). }\end{array}$ \\
\hline $\begin{array}{l}\text { Chu et al., } 2004 \\
\text { [17] }\end{array}$ & $\begin{array}{l}\text { Hong Kong (China), } \\
2002\end{array}$ & HMV & $\begin{array}{l}\text { Survey to consultants of } \\
\text { respiratory } \\
\text { medicine in all adult medical } \\
\text { departments of Hong Kong } \\
\text { Hospital Authority hospitals to } \\
\text { report } \\
\text { their adult patients ( }>18 \text { years) } \\
\text { who had ever } \\
\text { been managed by HMV }\end{array}$ & $\begin{array}{l}\text { Survey content: } \\
\text { demographic data, } \\
\text { mode of ventilation (non-invasive or tracheostomy } \\
\text { ventilation), } \\
\text { underlying disease, } \\
\text { indications for HMV, } \\
\text { time of starting ventilation, } \\
\text { time and reason of stopping ventilation, if any, in } \\
\text { the follow-up period. }\end{array}$ & $\begin{array}{l}249 \text { cases reported to the survey from } 14 \text { centers of } \\
\text { adult respiratory medicine; } \\
156 \text { males }(62.7 \%) \text { and } 93 \text { females }(37.3 \%) \text { with a } \\
\text { mean age of } 62.7 \pm 13.8 \text { years; } \\
80 \% \text { of HMV cases were under the care of six } \\
\text { major centers. } \\
197 \text { cases were continuing with HMV, } \\
\text { corresponding to } ~ 2.9 \text { HMV users per } 100,000 \\
\text { population. } \\
\text { The majority ( } n=236,94.8 \% \text { ) were treated by } \\
\text { noninvasive ventilation (NIV), with the remaining } \\
13 \text { patients ( } 5.2 \%) \text { receiving tracheostomy } \\
\text { ventilation. } \\
\text { All NIVs were provided by bilevel } \\
\text { pressure-support ventilators. All tracheostomized } \\
\text { cases were put on HMV after repeated failures to } \\
\text { wean. } \\
\text { The disease conditions for which HMV was } \\
\text { prescribed: COPD }(121,48.6 \%) \text {; Complicated } \\
\text { obstructive sleep apnea/obesity hypoventilation } \\
\text { syndrome ( } 43,17.2 \%) ; \text { and Restrictive thoracic } \\
\text { disorders }(85,34.1 \%) \text {. }\end{array}$ \\
\hline
\end{tabular}


Table 1. Cont

\begin{tabular}{|c|c|c|c|c|c|}
\hline $\begin{array}{l}\text { Author, } \\
\text { Year }\end{array}$ & $\begin{array}{l}\text { Region or Country, } \\
\text { Years Analyzed }\end{array}$ & Aim & Method & Data Collection & Results \\
\hline $\begin{array}{l}\text { Fauroux et al., } \\
2003 \text { [18] }\end{array}$ & France, 2000 & $\begin{array}{l}\text { Domiciliary non-invasive } \\
\text { mechanical ventilation } \\
\text { (NIMV) in children }\end{array}$ & $\begin{array}{l}\text { Anonymous national } \\
\text { cross-sectional } \\
\text { Survey } \\
\text { A postal questionnaire sent by the } \\
\text { Paediatric Group of the National } \\
\text { Home Care Organization } \\
\text { (ANTADIR) in } 1999 \text { to all } 64 \\
\text { senior pediatric respiratory, } \\
\text { neurology, and intensive care } \\
\text { physicians in France. } \\
\text { Patients aged < } 18 \text { years and } \\
\text { receiving home NIMV were } \\
\text { included in the study. }\end{array}$ & $\begin{array}{l}\text { All physicians taking care of children with NIMV } \\
\text { were sent a second questionnaire in } 2000 \text {. } \\
\text { The specific information requested on each patient } \\
\text { included: } \\
\text { Sex and date of birth; } \\
\text { Primary and secondary diagnosis; } \\
\text { Symptoms that justified NIMV; } \\
\text { Age at onset of NIMV; } \\
\text { Type of nasal mask, ventilatory mode, and } \\
\text { concurrent use of oxygen therapy; } \\
\text { Investigations performed before initiating of } \\
\text { NIMV and during follow-up. }\end{array}$ & 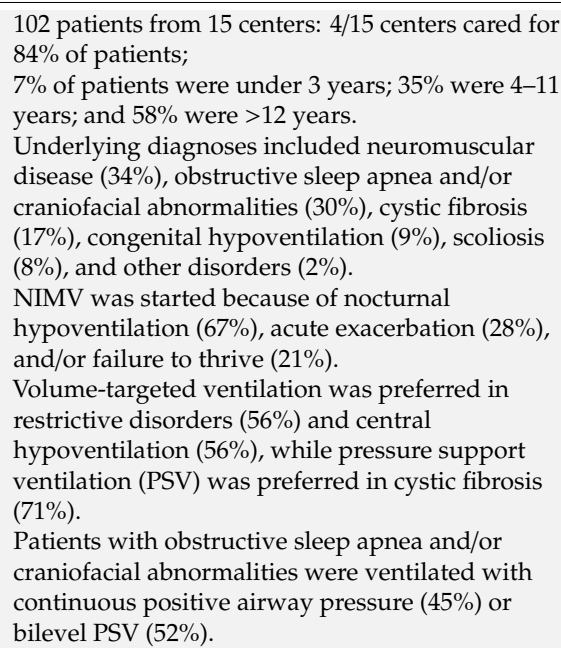 \\
\hline
\end{tabular}


Table 1. Cont.

\begin{tabular}{|c|c|c|c|c|c|}
\hline $\begin{array}{l}\text { Author, } \\
\text { Year }\end{array}$ & $\begin{array}{l}\text { Region or Country, } \\
\text { Years Analyzed }\end{array}$ & Aim & Method & Data Collection & Results \\
\hline $\begin{array}{l}\text { Wijkstra et al., } \\
2001[24]\end{array}$ & $\begin{array}{l}\text { Seven countries } \\
\text { (Brazil, Canada, } \\
\text { France, Italy, Spain, } \\
\text { Netherlands, USA), } \\
\text { NR }\end{array}$ & LTOT: prescription & $\begin{array}{l}\text { Questionnaire mailed to } 100 \\
\text { randomly selected respirologists } \\
\text { from a list of respiratory } \\
\text { specialists belonging to a } \\
\text { professional organization in each } \\
\text { country }\end{array}$ & $\begin{array}{l}\text { Characteristics of the respirologists: } \\
\text { Date of birth; } \\
\text { How many years they had been practicing } \\
\text { respiratory medicine; } \\
\text { Number of patients for whom they prescribed } \\
\text { oxygen for the first time or for renewal purposes } \\
\text { over the previous month. } \\
\text { Prescription of oxygen at rest; } \\
\text { Whether they prescribed a standard oxygen flow } \\
\text { rate for all their patients or whether they } \\
\text { individualized flow rates with or without specific } \\
\text { testing of each patient; } \\
\text { How the recommended oxygen flow at rest was } \\
\text { chosen (either tested at rest or tested during } \\
\text { exercise); } \\
\text { The position (sitting, semirecumbent, supine) in } \\
\text { which the patients were tested, } \\
\text { the target level of arterial oxygen saturation (SaO }{ }_{2} \text { ) } \\
\text { used to establish an oxygen prescription and the } \\
\text { percentage of time during the measure in which } \\
\text { this target had to be achieved. } \\
\text { Prescription of oxygen during sleep and exercise; } \\
\text { How they prescribed oxygen during sleep and } \\
\text { exercise; } \\
\text { The type of exercise test (walking, laboratory } \\
\text { testing) used to establish the exercise prescription; } \\
\text { The target level of saturation during exercise and } \\
\text { the percentage of time during the test in which } \\
\text { this target had to be achieved. }\end{array}$ & $\begin{array}{l}81 \% \text { of respondents individualized the oxygen } \\
\text { prescription at rest. } \\
\text { Resting } \mathrm{SaO}_{2} \text { was most commonly targeted at } \\
90-91 \% \text {. } \\
\text { The approach to night prescription varied. } \\
\text { Respirologists in Canada and the USA increased } \\
\text { the resting } \mathrm{SaO}_{2} \text { by } 1-2 \mathrm{~L} / \text { min during sleep, while } \\
\text { those in Spain used the resting flow for the night } \\
\text { prescription }(62 \%) \text {. } \\
\text { Respirologists in the Netherlands, France, and } \\
\text { Italy individualized the night prescription more } \\
\text { frequently. } \\
\text { Although oxygen during exercise was } \\
\text { individualized in most countries }(74 \%) \text {, significant } \\
\text { differences remained among countries. } \\
62 \% \text { of respirologists }(62 \%) \text { aimed to achieve an } \\
\mathrm{SaO}_{2} \text { of } 90-91 \% \text { during exercise, while } 70 \% \text { of all } \\
\text { respirologists tried to achieve the desired } \mathrm{SaO}_{2} \text { for } \\
90 \% \text { of the test. }\end{array}$ \\
\hline
\end{tabular}


Table 1. Cont.

\begin{tabular}{|c|c|c|c|c|c|}
\hline $\begin{array}{l}\text { Author, } \\
\text { Year }\end{array}$ & $\begin{array}{l}\text { Region or Country, } \\
\text { Years Analyzed }\end{array}$ & Aim & Method & Data Collection & Results \\
\hline $\begin{array}{l}\text { de Lucas } \\
\text { Ramos et al., } \\
2000 \text { [4] }\end{array}$ & Spain, 1998-1999 & HMV: prescription & $\begin{array}{l}\text { Questionnaire mailed to the } \\
\text { respiratory medicine } \\
\text { departments of } 200 \text { hospitals in } \\
\text { the public health system }\end{array}$ & $\begin{array}{l}\text { Survey Content: } \\
\text { Center name, } \\
\text { Year of initiation of the MV program, } \\
\text { Number of patients in the first year, } \\
\text { Number of patients in the current year. } \\
\text { Diagnosis: } \\
\text { Neuromuscular disease, } \\
\text { Thoracic cage disease, } \\
\text { Hypoventilation-obesity syndrome, } \\
\text { COPD, } \\
\text { Other. } \\
\text { Ventilation type: } \\
\text { Volumetric, } \\
\text { BI-level Positive Airway Pressure, } \\
\text { Interface, } \\
\text { Nasal mask, } \\
\text { Conventional, } \\
\text { Personalized, } \\
\text { Tracheostomy, } \\
\text { Mouthpiece. }\end{array}$ & $\begin{array}{l}43 \text { hospitals, } 1821 \text { patients; } \\
813 \text { patients had restrictive disease due to thoracic } \\
\text { cage disease, } 452 \text { neuromuscular disease, } 271 \\
\text { hypoventilation-obesity syndrome, } 162 \text { COPD, } \\
\text { and } 123 \text { other diseases/conditions. } \\
965 \text { ( } 53 \% \text { ) used pressure support devices and } 856 \\
(47 \%) \text { used volumetric ventilators. } \\
1320 \text { conventional nasal mask, } 336 \text { personalized } \\
\text { nasal mask, } 118 \text { tracheostomy, } 41 \text { facial mask, six } \\
\text { mouthpiece. }\end{array}$ \\
\hline
\end{tabular}


Table 1. Cont

\begin{tabular}{|c|c|c|c|c|c|}
\hline $\begin{array}{l}\text { Author, } \\
\text { Year }\end{array}$ & $\begin{array}{l}\text { Region or Country, } \\
\text { Years Analyzed }\end{array}$ & Aim & Method & Data Collection & Results \\
\hline $\begin{array}{l}\text { Fauroux et al., } \\
1994 \text { [19] }\end{array}$ & $\begin{array}{l}13 \text { European } \\
\text { countries (Belgium, } \\
\text { Denmark, England, } \\
\text { France, Germany, } \\
\text { Ireland, Italy, } \\
\text { Netherlands, } \\
\text { Norway, Poland, } \\
\text { Spain, Sweden, } \\
\text { Switzerland), } 1992\end{array}$ & $\begin{array}{l}\text { Home care of chronic } \\
\text { respiratory insufficiency }\end{array}$ & Questionnaire at the end of 1992. & $\begin{array}{l}\text { Questionnaire content: } \\
\text { Home treatments (LTOT, HMV); } \\
\text { Prescribers; } \\
\text { Practical organization of home care (supply of } \\
\text { material, supervision of patients and equipment). } \\
\text { Information on patients: } \\
\text { diagnostic information (either obstructive, } \\
\text { restrictive, or mixed pulmonary disease); } \\
\text { Age; } \\
\text { Sex; } \\
\text { Equipment supplied; } \\
\text { Service provided; } \\
\text { Therapeutic schedules. }\end{array}$ & $\begin{array}{l}\text { Information was easier to obtain for LTOT than for } \\
\text { HMV. } \\
\text { In all countries, both adults and children received } \\
\text { LTOT at home for lung diseases and other less } \\
\text { common problems, such as chest-wall deformities } \\
\text { and sequelae of tuberculosis. } \\
\text { Oxygen concentrators were used preferentially in } \\
\text { all countries except Italy ( } 80 \% \text { of the patients } \\
\text { received liquid oxygen), Denmark, spain, and the } \\
\text { Netherlands (cylinders were used by } 80 \% \text { of the } \\
\text { patients). } \\
\text { Both adults and children received HMV at home } \\
\text { for chronic lung disease, neuromuscular disease, } \\
\text { chest-wall deformities, and central } \\
\text { hypoventilation in all countries, except in } \\
\text { Denmark and Poland, where this treatment is } \\
\text { almost unknown in the home. } \\
\text { Home ventilator treatment was generally } \\
\text { performed by volume-cycled ventilators. } \\
\text { National prescription rules existed in some parts } \\
\text { of Spain, Switzerland, and Belgium. In other } \\
\text { countries, such as Germany, prescriptions relied } \\
\text { on recommendations elaborated by specialists or } \\
\text { international guidelines. } \\
\text { Service and equipment were provided by national } \\
\text { organizations, health services, commercial } \\
\text { companies, or hospitals. } \\
\text { Home supervision of the patient was performed } \\
\text { by a nurse and/or a doctor and equipment } \\
\text { maintenance by a technician. }\end{array}$ \\
\hline
\end{tabular}


Most studies included both children and adult patients in their analysis. Only one of the studies specifically focused on a pediatric population [18]. Questionnaires, having been used in 10 studies, were the preferred method of data collection. In five studies, existing databases from HRT registries or health services were used. Irrespective of the data collection method used, data on users (age, sex, and diagnosis), type and duration of respiratory therapy, and equipment and interfaces were the most commonly recorded. None of the 15 studies reported the patient's experience with HRT.

\subsection{Assessment of Patient Experience}

Assessing the patient experience has become a common approach to describing healthcare from the patient's point of view, evaluating the process of care, and measuring the outcome of care [25-27]. Both quantitative and qualitative methods are being used to assess patients' perception. Self-reported questionnaires, individual interviews, and focus groups are among the most frequently used methods of collecting data.

\subsubsection{Patient-Reported Experience Measures}

The development of self-reported questionnaires, namely, patient-reported experience measures (PREMs) and patient-reported outcome measures (PROMs), has exponentially increased in the last several years. These two types of questionnaires collect information about the patient's perspective but with distinct purposes. A PREM evaluates patients' perception of their personal experience of the healthcare received, while a PROM assesses the perception of their health status and health-related quality of life $[10,28]$. A combination of PROMs and PREMs is essential to fully understand the performance of healthcare systems. Moreover, both measures are useful to provide a patient-centered perspective of healthcare, but PREMs are more adequate to assess experience with healthcare.

Distinct instruments to assess the patient's experience with healthcare are available. Table 2 summarizes 14 instruments designed to assess the patient's experience with the provision of care in different clinical settings [29-34], hospital [35-38], primary care [39,40], intermediate care [41], and community [33,41]. The majority of such instruments are generic and designed to be used for a diverse range of health conditions. However, two of the described questionnaires were specifically developed for patients with chronic diseases [29,34], and one was intended particularly for patients with COPD [30]. The majority of PREMs were developed to target adult patients and tested in patients who were at least 15 years old. Only two developed instruments were tested with the carers of children [31,39]. English is the most common language used, with some instruments also in Norwegian [31,38,39], Italian [35,41], and Spanish [29]. Most instruments already had some of their psychometric properties explored, namely, their reliability and validity.

None of the instruments above were specifically designed to assess the patient's experience with HRT. However, a recent European Respiratory Society (ERS)/European Lung Foundation (ELF) survey was conducted across 11 European countries and assessed the attitudes and preferences of 687 patients on HMV and those of 100 carers [42]. A questionnaire was specifically developed for this study in eight languages (English, German, Dutch, Spanish, Italian, Portuguese, Greek, and French) and explored four areas: (1) patients' demographic and clinical characteristics; (2) issues influencing compliance, such as interface comfort, abilities to travel, sleep, and socialize with a ventilator, type and technical functioning of the ventilator (e.g., alarms, ability to operate and change settings, on/off switches, and electricity consumption); (3) support, training, and education; and (4) requests for improved devices and support.

Today, it is possible to evaluate a patient's perception of the HRT received using one of the described PREMs. Nevertheless, in the near future, the aim should be to develop a specific PREM to assess patients' personal experience with HRT. 
Table 2. Instruments designed to assess patient's experience with the provision of care.

\begin{tabular}{|c|c|c|c|c|c|c|}
\hline Instrument & Population & Setting & Language & Concepts & Structure & $\begin{array}{c}\text { Measurement } \\
\text { Properties }\end{array}$ \\
\hline $\begin{array}{l}\text { CEFIT: Care Experience } \\
\text { Feedback Improvement } \\
\text { Tool [36] }\end{array}$ & $\begin{array}{l}\text { Tested in } 802 \text { patients } \\
\text { ( } \geq 18 \text { years) with } \\
\text { healthcare experience. }\end{array}$ & Hospital & English & $\begin{array}{l}\text { Safe, } \\
\text { Timely, } \\
\text { System navigation, } \\
\text { Caring, } \\
\text { Effective. }\end{array}$ & $\begin{array}{l}\text { Five questions scored } \\
\text { using a five-point scale, } \\
\text { from } 1 \text { (never) to } 5 \\
\text { (always). }\end{array}$ & $\begin{array}{l}\text { Reliability } \\
\text { Validity }\end{array}$ \\
\hline $\begin{array}{l}\text { COPD PREM9: } \\
\text { disease-specific } \\
\text { patient-reported } \\
\text { experience measure in } \\
\text { COPD }[28,30]\end{array}$ & $\begin{array}{l}\text { Tested in } 174 \text { adult } \\
\text { patients with COPD. }\end{array}$ & $\begin{array}{l}\text { Clinical settings (e.g., } \\
\text { pulmonary rehabilitation, } \\
\text { nurse-led clinics, or GP } \\
\text { annual reviews) }\end{array}$ & English & $\begin{array}{l}\text { Everyday life with COPD, } \\
\text { Everyday care in COPD, } \\
\text { Self-management of } \\
\text { COPD, exacerbations. }\end{array}$ & $\begin{array}{l}\text { Nine questions scored } \\
\text { using a six-point scale, } \\
\text { from } 0 \text { (good experience) } \\
\text { to } 5 \text { (bad experience). }\end{array}$ & $\begin{array}{l}\text { Reliability } \\
\text { Validity }\end{array}$ \\
\hline $\begin{array}{l}\text { GS-PEQ: Generic Short } \\
\text { Patient Experiences } \\
\text { Questionnaire [31] }\end{array}$ & $\begin{array}{l}\text { Tested in } 1324 \\
\text { patients (including } \\
\text { outpatients } \\
\text { undergoing } \\
\text { rehabilitation and } \\
\text { carers of children). }\end{array}$ & $\begin{array}{l}\text { Services provided in a } \\
\text { range of specialist } \\
\text { healthcare (in- and } \\
\text { out-patient) }\end{array}$ & Norwegian & $\begin{array}{l}\text { Outcome, } \\
\text { Clinician services, } \\
\text { User involvement, } \\
\text { Incorrect treatment, } \\
\text { Information, } \\
\text { Organization, } \\
\text { Accessibility. }\end{array}$ & $\begin{array}{l}10 \text { questions scored using } \\
\text { a five-point scale, from } 1 \\
\text { (Not at all/Not important) } \\
\text { to } 5 \text { (To a very large } \\
\text { extent/Of utmost } \\
\text { importance). }\end{array}$ & Not reported \\
\hline $\begin{array}{l}\text { howRwe (how are we } \\
\text { doing?)questionnaire: } \\
\text { short generic patient } \\
\text { experience questionnaire } \\
{[32,43]}\end{array}$ & $\begin{array}{l}\text { Tested in } 828 \text { patients } \\
\text { in an orthopedic } \\
\text { pre-operative } \\
\text { assessment clinic [32] } \\
\text { and in } 90 \text { adult } \\
\text { patients ( } \geq 18 \text { years) } \\
\text { from general practices } \\
\text { (10 with COPD) [43]. }\end{array}$ & $\begin{array}{l}\text { Generic, applicable } \\
\text { without change across all } \\
\text { patient categories and } \\
\text { care settings, including } \\
\text { primary, secondary, } \\
\text { community, emergency, } \\
\text { domiciliary, and social } \\
\text { care. }\end{array}$ & English Dutch & $\begin{array}{l}\text { Clinical care (kindness } \\
\text { and communication), } \\
\text { Organization of care } \\
\text { (promptness and } \\
\text { organization). }\end{array}$ & $\begin{array}{l}\text { Four items scored using a } \\
\text { four-point scale from } 0 \\
\text { (poor) to } 3 \text { (excellent). }\end{array}$ & $\begin{array}{l}\text { Reliability } \\
\text { Validity }\end{array}$ \\
\hline
\end{tabular}


Table 2. Cont

\begin{tabular}{|c|c|c|c|c|c|c|}
\hline Instrument & Population & Setting & Language & Concepts & Structure & $\begin{array}{c}\text { Measurement } \\
\text { Properties }\end{array}$ \\
\hline $\begin{array}{l}\text { Health Services } \\
\text { OutPatient Experience } \\
\text { (HSOPE): global outcome } \\
\text { measure of perceived } \\
\text { patient-centeredness of } \\
\text { the outpatient healthcare } \\
\text { pathway [35] }\end{array}$ & $\begin{array}{l}\text { Tested in } 1532 \text { adult } \\
\text { outpatients ( } \geq 16 \\
\text { years) receiving care } \\
\text { (including } \\
\text { rehabilitation). }\end{array}$ & Hospital & Italian & $\begin{array}{l}\text { Perceived technical } \\
\text { effectiveness of the staff, } \\
\text { Information on } \\
\text { modalities of the } \\
\text { outpatient visit, on the } \\
\text { visit outcomes, and the } \\
\text { course of the healthcare } \\
\text { pathway, } \\
\text { Relational aspects of } \\
\text { outpatient-staff } \\
\text { interaction, } \\
\text { Involvement in decision } \\
\text { making. }\end{array}$ & $\begin{array}{l}10 \text { statements scored } \\
\text { using a five-point Likert } \\
\text { scale from } 1 \text { (never) to } 5 \\
\text { (always) } \\
1 \text { item scored using a } \\
\text { 10-point scale from } 1 \\
\text { (very dissatisfied) to } 10 \\
\text { (very satisfied). } \\
\text { Three sociodemographic } \\
\text { questions (sex, age, and } \\
\text { residence). } \\
\text { One question about } \\
\text { suggestions to improve } \\
\text { outpatient visits. }\end{array}$ & $\begin{array}{l}\text { Reliability } \\
\text { Validity }\end{array}$ \\
\hline $\begin{array}{l}\text { Intermediate } \\
\text { care-IC-PREMs: } \\
\text { Bed-Based } \\
\text { Patient-Reported } \\
\text { Experience Measure [41] }\end{array}$ & $\begin{array}{l}\text { Tested in } 1832 \text { adult } \\
\text { patients. }\end{array}$ & Bed-based IC services & English Italian & $\begin{array}{l}\text { Goal Setting, } \\
\text { Empowerment, } \\
\text { Self-Management, } \\
\text { Care-Planning, } \\
\text { Transitions, } \\
\text { Decision Making, } \\
\text { Communication. }\end{array}$ & $\begin{array}{l}15 \text { questions scored using } \\
\text { two, three, or four } \\
\text { response categories. }\end{array}$ & $\begin{array}{l}\text { Reliability } \\
\text { Validity }\end{array}$ \\
\hline $\begin{array}{l}\text { IC-PREMs: home-based } \\
\text { (and reablement-based) } \\
\text { Patient-Reported } \\
\text { Experience Measure [41] }\end{array}$ & $\begin{array}{l}\text { Tested in } 4627 \text { adult } \\
\text { patients. }\end{array}$ & $\begin{array}{l}\text { Home-based or } \\
\text { reablement IC services }\end{array}$ & English Italian & $\begin{array}{l}\text { Goal Setting, } \\
\text { Empowerment, } \\
\text { Self-Management, } \\
\text { Care-Planning, } \\
\text { Transitions, } \\
\text { Decision Making, } \\
\text { Communication. }\end{array}$ & $\begin{array}{l}15 \text { questions scored using } \\
\text { two, three, or four } \\
\text { response categories. }\end{array}$ & $\begin{array}{l}\text { Reliability } \\
\text { Validity }\end{array}$ \\
\hline
\end{tabular}


Table 2. Cont

\begin{tabular}{|c|c|c|c|c|c|c|}
\hline Instrument & Population & Setting & Language & Concepts & Structure & $\begin{array}{c}\text { Measurement } \\
\text { Properties }\end{array}$ \\
\hline $\begin{array}{l}\text { IEXPAC, Instrument for } \\
\text { Evaluation of the } \\
\text { Experience of Chronic } \\
\text { Patients [29] }\end{array}$ & $\begin{array}{l}\text { Tested in } 356 \text { patients } \\
\text { ( } \geq 16 \text { years) with } \\
\text { chronic diseases ( } 20 \% \\
\text { with COPD). }\end{array}$ & Health and social services & Spanish & $\begin{array}{l}\text { Type and scope of patient } \\
\text { and professional } \\
\text { interactions oriented to } \\
\text { patient activation. } \\
\text { Patient's } \\
\text { self-management capacity } \\
\text { of his/her wellbeing } \\
\text { resulting from the } \\
\text { interventions received. } \\
\text { New relational model of } \\
\text { the patient with the } \\
\text { system through the } \\
\text { internet or with partners } \\
\text { in group intervention. }\end{array}$ & $\begin{array}{l}11+1 \text { items scored using } \\
\text { a five-point scale from } 0 \\
\text { (never) to } 10 \text { (always). } \\
\text { Since } 2018 \text {, a new version } \\
\text { with } 11+4 \text { items is used, } \\
\text { with three additional } \\
\text { items. }\end{array}$ & $\begin{array}{l}\text { Reliability } \\
\text { Validity }\end{array}$ \\
\hline $\begin{array}{l}\text { LifeCourse experience } \\
\text { tool [33] }\end{array}$ & $\begin{array}{l}\text { Tested in } 607 \text { adult } \\
\text { patients with } \\
\text { emergency } \\
\text { department and } \\
\text { in-patient utilization, } \\
\text { advanced primary } \\
\text { diagnosis of heart } \\
\text { failure, cancer, or } \\
\text { dementia. }\end{array}$ & $\begin{array}{l}\text { Home, Nursing Homes, } \\
\text { Assisted living }\end{array}$ & English & $\begin{array}{l}\text { Care Team, } \\
\text { Communication, } \\
\text { Care Goals. }\end{array}$ & $\begin{array}{l}22 \text { items scored using a } \\
\text { four-point scale from } 1 \\
\text { (Never or Strongly } \\
\text { Disagree) to } 4 \text { (Always or } \\
\text { Strongly Agree). }\end{array}$ & $\begin{array}{l}\text { Reliability } \\
\text { Validity }\end{array}$ \\
\hline $\begin{array}{l}\text { Multidimensional } \\
\text { Semantic Patient } \\
\text { Experience Measurement } \\
\text { Questionnaire [37] }\end{array}$ & $\begin{array}{l}\text { Tested in } 60 \text { patients } \\
(\geq 15 \text { years }) \\
\text { undergoing a } \\
\text { magnetic resonance } \\
\text { scan. }\end{array}$ & Hospital & English & $\begin{array}{l}\text { Evaluation/valence, } \\
\text { Potency/control, } \\
\text { Activity/arousal, } \\
\text { Novelty. }\end{array}$ & $\begin{array}{l}12 \text { rating scales using a } \\
\text { seven-point bipolar } \\
\text { attribute rating scales: } \\
\text { 'extremely', 'quite', } \\
\text { 'slightly', 'neither', } \\
\text { 'slightly', 'quite', and } \\
\text { 'extremely'. }\end{array}$ & Reliability \\
\hline
\end{tabular}


Table 2. Cont.

\begin{tabular}{|c|c|c|c|c|c|c|}
\hline Instrument & Population & Setting & Language & Concepts & Structure & $\begin{array}{c}\text { Measurement } \\
\text { Properties }\end{array}$ \\
\hline $\begin{array}{l}\text { PEQ: Patient experience } \\
\text { questionnaire } 2001 \text { [39] }\end{array}$ & $\begin{array}{l}\text { Tested in } 1092 \\
\text { patients (1-91 } \\
\text { years)/carers }\end{array}$ & Primary care & Norwegian & $\begin{array}{l}\text { Communication, } \\
\text { Emotions, } \\
\text { Short-term outcome, } \\
\text { Barriers, } \\
\text { Relations with auxiliary } \\
\text { staff. }\end{array}$ & $\begin{array}{l}\text { Total } 18 \text { items: } \\
\text { Four items using a } \\
\text { five-point scale from } 1 \\
\text { ('no more' or 'nothing') to } \\
5 \text { ('much more' or 'a lot'). } \\
10 \text { items using a } \\
\text { five-point scale from } 1 \\
\text { (disagree completely) to } 5 \\
\text { (agree completely). } \\
\text { Four items were formed } \\
\text { on seven-point scales. }\end{array}$ & $\begin{array}{l}\text { Reliability } \\
\text { Validity }\end{array}$ \\
\hline $\begin{array}{l}\text { PEQ: Patient Experiences } \\
\text { Questionnaire } 2004 \text { [38] }\end{array}$ & $\begin{array}{l}\text { Tested in } 19578 \\
\text { patients ( } \geq 16 \text { years) } \\
\text { with experience with } \\
\text { surgical wards and } \\
\text { wards of internal } \\
\text { medicine }\end{array}$ & Hospital & Norwegian & $\begin{array}{l}\text { Information on future } \\
\text { complaints, } \\
\text { Nursing services, } \\
\text { Communication, } \\
\text { Information } \\
\text { examinations, } \\
\text { Contact with next-of-kin, } \\
\text { Doctor services, } \\
\text { Hospital and equipment, } \\
\text { Information medication, } \\
\text { Organization, } \\
\text { General satisfaction. }\end{array}$ & $\begin{array}{l}35 \text { items with } 10 \text {-point } \\
\text { ordinal response scales } \\
\text { from } 1 \text { (negative) to } 10 \\
\text { (positive). }\end{array}$ & $\begin{array}{l}\text { Reliability } \\
\text { Validity }\end{array}$ \\
\hline $\begin{array}{l}\text { PACIC: Patient } \\
\text { Assessment of Chronic } \\
\text { Illness Care }[34,44]\end{array}$ & $\begin{array}{l}\text { Tested in } 4108 \text { adult } \\
\text { patients with diabetes, } \\
\text { chronic pain, heart } \\
\text { failure, asthma, } \\
\text { coronary artery } \\
\text { disease. }\end{array}$ & $\begin{array}{l}\text { Chronic care } \\
\text { management }\end{array}$ & English & $\begin{array}{l}\text { Patient activation, } \\
\text { Delivery system design, } \\
\text { Goal setting, } \\
\text { Problem solving, } \\
\text { Follow-up/coordination. } \\
\text { Focuses on the receipt of } \\
\text { patient-centered care and } \\
\text { self-management } \\
\text { behaviors. }\end{array}$ & $\begin{array}{l}20 \text { items using a } \\
\text { five-point scale from } 1 \\
\text { (Almost Never) to } 5 \\
\text { (Almost Always). }\end{array}$ & $\begin{array}{l}\text { Reliability } \\
\text { Validity }\end{array}$ \\
\hline
\end{tabular}


Table 2. Cont.

\begin{tabular}{|c|c|c|c|c|c|c|}
\hline Instrument & Population & Setting & Language & Concepts & Structure & $\begin{array}{c}\text { Measurement } \\
\text { Properties }\end{array}$ \\
\hline $\begin{array}{l}\text { ACES-SF: Ambulatory } \\
\text { Care Experiences Survey } \\
{[40]}\end{array}$ & $\begin{array}{l}\text { Tested in } 49,861 \text { adult } \\
\text { patients. }\end{array}$ & Primary care & English & $\begin{array}{l}\text { Quality of } \\
\text { physician-patient } \\
\text { interaction, } \\
\text { Health promotion } \\
\text { support, } \\
\text { Care coordination, } \\
\text { Organizational access, } \\
\text { Office staff interactions, } \\
\text { An additional item to } \\
\text { assess patients' } \\
\text { willingness to } \\
\text { recommend the physician } \\
\text { to family and friends. }\end{array}$ & $\begin{array}{l}18 \text { items using continuous } \\
\text { responses: Never, Almost } \\
\text { never, sometimes, } \\
\text { Usually, Almost always, } \\
\text { Always; or Yes, definitely, } \\
\text { Yes, somewhat, No, } \\
\text { definitely not; or } \\
\text { Definitely yes, Probably } \\
\text { yes, Not sure, Probably } \\
\text { not, Definitely not. }\end{array}$ & $\begin{array}{l}\text { Reliability } \\
\text { Validity }\end{array}$ \\
\hline
\end{tabular}




\subsubsection{Individual Interviews and Focus Groups}

Qualitative studies that explore the experience of patients receiving HRT are still limited in the literature. Nevertheless, the literature review revealed some studies that explored the experience of patients living with COPD, pulmonary fibrosis, and OSA. These studies specifically focused on patients' needs and the adaptation process to respiratory therapies. Two studies explored the patient's experience with LTOT [45,46], and the others assessed the patient's experience with non-invasive ventilation [47-51]. These studies were conducted in the United States of America [45,47], New Zealand [48,49], the United Kingdom [50], Sweden [51], and Spain [46] and included both adult patients and carers. Two reviews were also found on the needs of patients with COPD and were also used in the present analysis [52,53].

From the analysis of these studies, it was possible to clearly identify education, training, support, and carer involvement as important key-points in facilitating a patient's treatment experience and subsequent adherence. Below, each one of these four key-points is described in detail.

Education: on the basis of the perspectives of patients, it is apparent that education is crucial for defining clear expectations about the treatment and motivating patient adherence. The main education topics raised by patients receiving respiratory therapies are related to disease self-management (e.g., COPD, OSA); physical effects and potential clinical benefits of the respiratory therapy; risks of not using the respiratory therapy; guidance on the use and function of equipment (e.g., continuous positive airway pressure (CPAP) devices, oxygen concentrators, how to use pulse oximeters and adjust flow with exertion); side effects and guidance on its management (skin protection, dry mouth, nasal congestion, irritated eyes); traveling with equipment; follow-up appointments; and assistance with financial elements (e.g., how to claim electricity costs) $[45,46,49,50]$.

Training: formal training on appropriate equipment use has been suggested to be an important strategy for improving adherence [46-51]. Healthcare professionals need to introduce the device, explore possible practical problems, and give advice/help to solve these problems. In their initial experiences with respiratory therapy, patients should have a hands-on demonstration for setting up the device, trialing different masks/pressures, making mask adjustments, conquering different side-effects, and finding the best position for the tubing or machine (also considering the loudness of the device). Regular follow up visits or phone calls are important to assess practical problems being experienced (e.g., pressure from the mask, mask leakage, disturbing noise, and difficulties changing sleeping positions) and to discuss effective strategies to address them.

Support: establishing a trustworthy relationship with healthcare professionals after the initiation of respiratory therapy is perceived as helpful by patients, and these relationships positively influence their adherence [46]. Healthcare professionals need to foster a non-judgmental environment in which patients have opportunities to ask questions, share concerns and feelings, feel listened to, and feel understood. This is particularly important following the initiation of therapy [47], as questions or concerns are more likely to arise during the first days or weeks of treatment $[49,52]$. These opportunities can arise during regular follow-up visits, scheduled follow-up phone calls, and through access to a 24-h hotline [47].

Carer involvement: carers provide substantial care (emotional, physical) to the individual on a daily basis and, most of the time, live in the same house as the patient. On the basis of their important role in patients' lives, carer involvement has been found to be essential to patients receiving HRT [45-48,50-53]. Patients recognize that carers play a major role in their treatment by helping them manage the disease and adapt to the equipment (e.g., verbal reminders, encouragement, setting up the machine, making mask adjustments, reassurance of therapy benefits). Carers themselves recognize their need for information regarding aspects of the disease and benefits of the HRT [47]. Carer involvement is thus perceived by all stakeholders as an essential component of education and training from the beginning of treatment $[45,47,48,50-53]$, and it is generally associated with positive results, namely, the patients' adoption and adherence to HRT [47,53]. 


\section{Discussion}

This comprehensive review is a first critical step toward the assessment of the patient experience in the clinical context of HRT. It demonstrates that research in this area is still limited, with no example of an HRT prescription model that incorporates the patient experience as an outcome and with no specific PREM available. This review also shows that European countries have been involved in HRT provision research from an early stage.

Most of the research on the assessment of HRT prescription models has been conducted within the last decade and mainly in European countries, highlighting the emergent interest and Europe's leading position in this area of health research. In addition, HMV has attracted more attention from the scientific community in comparison with LTOT. Questionnaires were found to be the preferred method for data collection, however, existing databases from HRT registries or health services have also been used. Databases in comparison with questionnaires have the advantage of generating more representative data and may be a method of choice in future studies. The patient experience has not been examined in the assessment of the prescription models presented. While this reality was expected from the oldest studies, it was quite a surprising result for those from the last decade. These results show that, until now, the assessment of patients' perceptions has not been seen as a priority in the assessment of prescription models. Unfortunately, this is also a reality in other health contexts and settings [10]. The Organisation for Economic Co-operation and Development (OECD) and Europe in "Health at a Glance: Europe 2018" reported critical gaps in the data on patient-reported experience, and they recommended collecting data on the patient experience from any doctor in ambulatory care settings [10]. Thus, future studies on the provision of HRT should address this important gap in the literature.

To address this gap, we need to be aware of the current methods being used to assess the patient experience. Different instruments used at distinct levels of healthcare are available and described in this review. These instruments were developed to be completed by adult patients and, in some cases, by carers of children. In our opinion, although the carers' perspective is, of course, incredibly valuable, it should do not replace the children's experience. The development of PREMs for pediatric populations is crucial to the collection of information on the experience and outcome of children's care. Additionally, as previously mentioned, none of the instruments have been specifically designed to assess the patient's experience with HRT. The development of a specific PREM for this health context should be a research priority in the upcoming years. The most commonly assessed domains in the described instruments, including the ERS/ELF survey, together with the key facilitators of the patient's treatment experience, can be used as important sources of data to inform the development of a comprehensive instrument. Access to information and support, implementation of effective and clear communication, active participation in shared decision making, enhanced accessibility and navigability across the healthcare system for patients and families, particularly across transitional care, and management of polypharmacy are known to influence the patient experience in other healthcare settings and could be topics of interest to be included in future PREMs for patients on HRT [54]. Future studies should explore which of these raised topics are indeed meaningful for patients and carers.

On the basis of qualitative studies, it was found that education, training, support, and carer involvement were important key-points in facilitating the patient's treatment experience and adherence. This knowledge comes mainly from the perspective of adult patients with COPD, pulmonary fibrosis, and OSA receiving CPAP and from their carers. These studies were conducted in five countries (three from Europe) [45-53]. Thus, this evidence may not completely apply to the experience of younger patients (including children) and that of their carers or to patients with other diseases and other treatment modalities (e.g., Bilevel Positive Pressure Airway, LTOT) and from other countries/continents. Considering these identified gaps, the experience of other patients receiving HRT could be explored in future studies. The identified key-points may inform the development process of semi-structured guides of focus groups or individual interviews to be used in these exploratory studies. 


\section{Conclusions}

To the authors' best knowledge, this is the first published work to review the emerging topic of the patient experience in the clinical context of HRT and give important insights into the status of this clinical research area while also pointing out possible directions in which to move to realize patient-centered care. The assessment of the patient experience is in its early stages, and further research is needed to integrate these measures with routine healthcare delivery and the core set of healthcare quality indicators, as well as and to drive quality improvements in HRT.

Author Contributions: Conceptualization, C.C., C.J., J.A.F., J.E., and J.C.W.; writing-original draft preparation, C.C. and C.J.; writing-review and editing, S.M.A., J.R.C., J.A.F., J.E., and J.C.W.; project administration, C.C., S.M.A., J.R.C., and J.C.W.

Funding: C.J. has a post-doctoral grant (SFRH/BPD/115169/2016) funded by Fundação para a Ciência e a Tecnologia (FCT), co-financed by the European Social Fund (POCH) and Portuguese national funds from MCTES (Ministério da Ciência, Tecnologia e Ensino Superior).

Conflicts of Interest: The authors declare no conflict of interest.

\section{References}

1. Cranston, J.; Crockett, A.; Moss, J.; Alpers, J. Domiciliary oxygen for chronic obstructive pulmonary disease. Cochrane Database Syst. Rev. 2005, 4, CD001744. [CrossRef] [PubMed]

2. Annane, D.; Orlikowski, D.; Chevret, S. Nocturnal mechanical ventilation for chronic hypoventilation in patients with neuromuscular and chest wall disorders. Cochrane Database Syst. Rev. 2014, 12, CD001941. [CrossRef] [PubMed]

3. Melo, I. Alguns dados sobre a Assistência Respiratória Domiciliária em Portugal. Rev. Port. Pneumol. 1997, 3, 481-492. [CrossRef]

4. De Lucas Ramos, P.; Rodríguez González-Moro, J.M.; Santa-Cruz Siminiani, A.; Cubillo Marcos, J.M.; Paz González, L. Estado actual de la ventilación mecánica domiciliaria en España: Resultados de una encuesta de ámbito nacional. Arch. Bronconeumol. 2000, 36, 545-550. (In Spanish) [CrossRef]

5. Lloyd-Owen, S.J;; Donaldson, G.C.; Ambrosino, N.; Escarabill, J.; Farre, R.; Fauroux, B.; Robert, D.; Schoenhofer, B.; Simonds, A.K.; Wedzicha, J.A. Patterns of home mechanical ventilation use in Europe: Results from the Eurovent survey. Eur. Respir. J. 2005, 25, 1025-1031. [CrossRef] [PubMed]

6. World Health Organization. What is Quality of Care and Why Is It Important? Available online: http: //www.who.int/maternal_child_adolescent/topics/quality-of-care/definition/en/ (accessed on 11 April 2019).

7. Simonds, A.K. Home Mechanical Ventilation: An Overview. Ann. Am. Thorac. Soc. 2016, 13, 2035-2044. [CrossRef]

8. Dogan, O.T.; Turkyilmaz, S.; Berk, S.; Epozturk, K.; Akkurt, I. Effects of long-term non-invasive home mechanical ventilation on chronic respiratory failure. Curr. Med. Res. Opin. 2010, 26, 2229-2236. [CrossRef]

9. NHS Department of Health. High Quality Care for All: NHS Next Stage Review Final Report; Norwich, UK, 2008. Available online: https://assets.publishing.service.gov.uk/government/uploads/system/uploads/attachment_ data/file/228836/7432.pdf (accessed on 11 April 2019).

10. OECD/EU. Health at a Glance: Europe 2018: State of Health in the EU Cycle. OECD Publishing: Paris, France, 2018. Available online: https://doi.org/10.1787/health_glance_eur-2018-en (accessed on 11 April 2019).

11. Doyle, C.; Lennox, L.; Bell, D. A systematic review of evidence on the links between patient experience and clinical safety and effectiveness. BMJ Open 2013, 3, e001570. [CrossRef]

12. Rose, L.; McKim, D.A.; Katz, S.L.; Leasa, D.; Nonoyama, M.; Pedersen, C.; Goldstein, R.S.; Road, J.D. Home mechanical ventilation in Canada: A national survey. Respir. Care 2015, 60, 695-704. [CrossRef]

13. Escarrabill, J.; Tebe, C.; Espallargues, M.; Torrente, E.; Tresserras, R.; Argimon, J. Variability in home mechanical ventilation prescription. Arch. Bronconeumol. 2015, 51, 490-495. [CrossRef]

14. Nasilowski, J.; Wachulski, M.; Trznadel, W.; Andrzejewski, W.; Migdal, M.; Drozd, W.; Pytel, A.; Suchanke, R.; Czajkowska-Malinowska, M.; Majszyk, T.; et al. The evolution of home mechanical ventilation in poland between 2000 and 2010. Respir. Care 2015, 60, 577-585. [CrossRef] [PubMed] 
15. Garner, D.J.; Berlowitz, D.J.; Douglas, J.; Harkness, N.; Howard, M.; McArdle, N.; Naughton, M.T.; Neill, A.; Piper, A.; Yeo, A.; et al. Home mechanical ventilation in Australia and New Zealand. Eur. Respir. J. 2013, 41, 39-45. [CrossRef] [PubMed]

16. Mandal, S.; Suh, E.; Davies, M.; Smith, I.; Maher, T.M.; Elliott, M.W.; Davidson, A.C.; Hart, N. Provision of home mechanical ventilation and sleep services for England survey. Thorax 2013, 68, 880-881. [CrossRef]

17. Chu, C.M.; Yu, W.C.; Tam, C.M.; Lam, C.W.; Hui, D.S.; Lai, C.K. Home mechanical ventilation in Hong Kong. Eur. Respir. J. 2004, 23, 136-141. [CrossRef]

18. Fauroux, B.; Boffa, C.; Desguerre, I.; Estournet, B.; Trang, H. Long-term noninvasive mechanical ventilation for children at home: A national survey. Pediatr. Pulmonol. 2003, 35, 119-125. [CrossRef] [PubMed]

19. Fauroux, B.; Howard, P.; Muir, J.F. Home treatment for chronic respiratory insufficiency: The situation in Europe in 1992. The European Working Group on Home Treatment for Chronic Respiratory Insufficiency. Eur. Respir. J. 1994, 7, 1721-1726. [CrossRef]

20. Ekstrom, M.; Ahmadi, Z.; Larsson, H.; Nilsson, T.; Wahlberg, J.; Strom, K.E.; Midgren, B. A nationwide structure for valid long-term oxygen therapy: 29-year prospective data in Sweden. Int. J. Chron. Obstruct. Pulmon. Dis. 2017, 12, 3159-3169. [CrossRef] [PubMed]

21. Ringbaek, T.J.; Lange, P. Trends in long-term oxygen therapy for COPD in Denmark from 2001 to 2010. Respir. Med. 2014, 108, 511-516. [CrossRef]

22. Serginson, J.G.; Yang, I.A.; Armstrong, J.G.; Cooper, D.M.; Matthiesson, A.M.; Morrison, S.C.; Gair, J.M.; Cooper, B.; Zimmerman, P.V. Variability in the rate of prescription and cost of domiciliary oxygen therapy in Australia. Med. J. Aust. 2009, 191, 549-553.

23. Jones, A.; Wood-Baker, R.; Walters, E.H. Domiciliary oxygen therapy services in Tasmania: Prescription, usage and impact of a specialist clinic. Med. J. Aust. 2007, 186, 632-634. [PubMed]

24. Wijkstra, P.J.; Guyatt, G.H.; Ambrosino, N.; Celli, B.R.; Güell, R.; Muir, J.F.; Préfaut, C.; Mendes, E.S.; Ferreira, I.; Austin, P.; et al. International approaches to the prescription of long-term oxygen therapy. Eur. Respir. J. 2001, 18, 909-913. [CrossRef] [PubMed]

25. Sitzia, J.; Wood, N. Patient satisfaction: A review of issues and concepts. Soc. Sci. Med. 1997, 45, 1829-1843. [CrossRef]

26. Donabedian, A. Evaluating the Quality of Medical Care. Milbank Q. 2005, 83, 691-729. [CrossRef] [PubMed]

27. Tarlov, A.R.; Ware, J.E., Jr.; Greenfield, S.; Nelson, E.C.; Perrin, E.; Zubkoff, M. The Medical Outcomes Study. An application of methods for monitoring the results of medical care. JAMA 1989, 262, 925-930. [CrossRef] [PubMed]

28. Hodson, M.; Andrew, S.; Michael Roberts, C. Towards an understanding of PREMS and PROMS in COPD. Breathe 2013, 9, 358-364. [CrossRef]

29. Mira, J.J.; Nuno-Solinis, R.; Guilabert-Mora, M.; Solas-Gaspar, O.; Fernandez-Cano, P.; Gonzalez-Mestre, M.A.; Contel, J.C.; Del Rio-Camara, M. Development and Validation of an Instrument for Assessing Patient Experience of Chronic Illness Care. Int. J. Integr. Care 2016, 16, 13. [CrossRef] [PubMed]

30. Hodson, M. Development of a Patient Reported Experience Measure in Chronic Obstructive Pulmonary Disease (COPD). Ph.D. Thesis, University of Portsmouth, Hampshire, UK, 2018.

31. Sjetne, I.S.; Bjertnaes, O.A.; Olsen, R.V.; Iversen, H.H.; Bukholm, G. The Generic Short Patient Experiences Questionnaire (GS-PEQ): Identification of core items from a survey in Norway. BMC Health Serv. Res. 2011, 11, 88. [CrossRef]

32. Benson, T.; Potts, H.W. A short generic patient experience questionnaire: howRwe development and validation. BMC Health Serv. Res. 2014, 14, 499. [CrossRef]

33. Fernstrom, K.M.; Shippee, N.D.; Jones, A.L.; Britt, H.R. Development and validation of a new patient experience tool in patients with serious illness. BMC Palliat. Care 2016, 15, 99. [CrossRef]

34. Schmittdiel, J.; Mosen, D.M.; Glasgow, R.E.; Hibbard, J.; Remmers, C.; Bellows, J. Patient Assessment of Chronic Illness Care (PACIC) and improved patient-centered outcomes for chronic conditions. J. Gen. Intern. Med. 2008, 23, 77-80. [CrossRef]

35. Coluccia, A.; Ferretti, F.; Pozza, A. Health Services OutPatient Experience questionnaire: Factorial validity and reliability of a patient-centered outcome measure for outpatient settings in Italy. Patient Relat. Outcome Meas. 2014, 5, 93-103. 
36. Beattie, M.; Shepherd, A.; Lauder, W.; Atherton, I.; Cowie, J.; Murphy, D.J. Development and preliminary psychometric properties of the Care Experience Feedback Improvement Tool (CEFIT). BMJ Open 2016, 6, e010101. [CrossRef]

37. Kleiss, J.A. Preliminary Development of a Multidimensional Semantic Patient Experience Measurement Questionnaire. Herd 2016, 10, 52-64. [CrossRef]

38. Pettersen, K.I.; Veenstra, M.; Guldvog, B.; Kolstad, A. The Patient Experiences Questionnaire: Development, validity and reliability. Int. J. Qual. Health Care 2004, 16, 453-463. [CrossRef]

39. Steine, S.; Finset, A.; Laerum, E. A new, brief questionnaire (PEQ) developed in primary health care for measuring patients' experience of interaction, emotion and consultation outcome. Fam. Pract. 2001, 18, 410-418. [CrossRef]

40. Rodriguez, H.P.; von Glahn, T.; Grembowski, D.E.; Rogers, W.H.; Safran, D.G. Physician effects on racial and ethnic disparities in patients' experiences of primary care. J. Gen. Intern. Med. 2008, 23, 1666-1672. [CrossRef]

41. Teale, E.A.; Young, J.B. A Patient Reported Experience Measure (PREM) for use by older people in community services. Age Ageing 2015, 44, 667-672. [CrossRef]

42. Masefield, S.; Vitacca, M.; Dreher, M.; Kampelmacher, M.; Escarrabill, J.; Paneroni, M.; Powell, P.; Ambrosino, N. Attitudes and preferences of home mechanical ventilation users from four European countries: An ERS/ELF survey. ERJ Open Res. 2017, 3, 00015-02017. [CrossRef]

43. Hendriks, S.H.; Rutgers, J.; van Dijk, P.R.; Groenier, K.H.; Bilo, H.J.G.; Kleefstra, N.; Kocks, J.W.H.; van Hateren, K.J.J.; Blanker, M.H. Validation of the howRu and howRwe questionnaires at the individual patient level. BMC Health Serv. Res. 2015, 15, 447. [CrossRef]

44. Glasgow, R.E.; Wagner, E.H.; Schaefer, J.; Mahoney, L.D.; Reid, R.J.; Greene, S.M. Development and validation of the Patient Assessment of Chronic Illness Care (PACIC). Med. Care 2005, 43, 436-444. [CrossRef]

45. Holm, K.E.; Casaburi, R.; Cerreta, S.; Gussin, H.A.; Husbands, J.; Porszasz, J.; Prieto-Centurion, V.; Sandhaus, R.A.; Sullivan, J.L.; Walsh, L.J.; et al. Patient Involvement in the Design of a Patient-Centered Clinical Trial to Promote Adherence to Supplemental Oxygen Therapy in COPD. Patient 2016, 9, 271-279. [CrossRef]

46. Clèries, X.; Solà, M.; Chiner, E.; Escarrabill, J. Aproximación a la experiencia del paciente y sus cuidadores en la oxigenoterapia domiciliaria. Arch. Bronconeumol. 2016, 52, 131-137. (In Spanish) [CrossRef] [PubMed]

47. Luyster, F.S.; Dunbar-Jacob, J.; Aloia, M.S.; Martire, L.M.; Buysse, D.J.; Strollo, P.J. Patient and partner experiences with obstructive sleep apnea and CPAP treatment: A qualitative analysis. Behav. Sleep Med. 2016, 14, 67-84. [CrossRef] [PubMed]

48. Ward, K.; Gott, M.; Hoare, K. Making choices about CPAP: Findings from a grounded theory study about living with CPAP. Collegian 2017, 24, 371-379. [CrossRef]

49. Gibson, R.; Campbell, A.; Mather, S.; Neill, A. From diagnosis to long-term treatment: The experiences of older New Zealanders with obstructive sleep apnoea. J. Prim. Health Care. 2018, 2, 140-149. [CrossRef] [PubMed]

50. Gale, N.K.; Jawad, M.; Dave, C.; Turner, A.M. Adapting to domiciliary non-invasive ventilation in chronic obstructive pulmonary disease: A qualitative interview study. Palliat. Med. 2015, 29, 268-277. [CrossRef] [PubMed]

51. Brostrom, A.; Nilsen, P.; Johansson, P.; Ulander, M.; Stromberg, A.; Svanborg, E.; Fridlund, B. Putative facilitators and barriers for adherence to CPAP treatment in patients with obstructive sleep apnea syndrome: A qualitative content analysis. Sleep Med. 2010, 11, 126-130. [CrossRef]

52. Gardener, A.C.; Ewing, G.; Kuhn, I.; Farquhar, M. Support needs of patients with COPD: A systematic literature search and narrative review. Int. J. Chron. Obstruct. Pulmon. Dis. 2018, 13, 1021-1035. [CrossRef] [PubMed]

53. Katsenos, S.; Constantopoulos, S.H. Long-Term Oxygen Therapy in COPD: Factors Affecting and Ways of Improving Patient Compliance. Pulm. Med. 2011, 2011, 325362. [CrossRef]

54. Fujisawa, R.; Klazinga, N.S. Measuring patient experiences (PREMS): Progress made by the OECD and its member countries between 2006 and 2016. OECD Health Work. Pap. 2017. [CrossRef]

(C) 2019 by the authors. Licensee MDPI, Basel, Switzerland. This article is an open access article distributed under the terms and conditions of the Creative Commons Attribution (CC BY) license (http://creativecommons.org/licenses/by/4.0/). 